\title{
The Impacts of Environment on Plant Products
}

\author{
E. Ceyhan, A. Kahraman, and M. Onder
}

\begin{abstract}
Plant species depend on specific environment conditions to optimum growing. There are various agricultural areas that comprised from plant species which originated in climatically quite different regions. Plants absorb many elements from soil which have biological function and some of them are known as toxic also at low amounts. In case of environmental conditions change, plants will response as changing some of their metabolic activities. So that some of the quality parameters will change. Some of the plants can adopt as well as reasonable values, but some of them will be affected negatively. Although human are not able to or has limits to change ecological situations, they also able to recognize some characteristics of plants and again can develop new plant species and regulate or eliminate some of the harmful effects of environment on plant quality parameters for adaptation to different climatic conditions. If we know the effects of ecological conditions on plants, the definition and improvement of plant quality parameters will be easy. Therefore plants are the basic place of food chain; there are some sorrows about their quality and credibility.
\end{abstract}

Index Terms-Environment, food quality, human nutrition, inhibitors.

\section{INTRODUCTION}

Environmental is a concept that encompasses all the factors that affect an organism and this term also among the basic terms of ecology. Any organism is not independent from its own environment. Environment includes all internal-external factors and forces also for plants. External factors cover light, water, temperature, wind, soil etc. elements [1]. One of neglect related to the affects of globally climate change is about their impacts on the food quality [2]. There are different microenvironment and microclimate modeling techniques for plants [3]. But they are still limited and expensive for extensively using.

Features of the environment are determined by the contributions of factors that constitute it. Impact degrees of factors vary as depend on plant species. For example, while cool climate legumes (peas, broad beans, chickpeas and lentils) show the best developments around $18-20{ }^{\circ} \mathrm{C}$, hot-climate legumes (beans, cowpeas) show a better development around $20-24{ }^{\circ} \mathrm{C}$. This shows us the plants are

revised January 31, 2012. This work was supported in part by the "Selcuk University, Coordinator of Scientific Research Projects" under project number 11701821. Some part of this article was presented as title of "Environmental Effects on Quality Parameters of Plant Products" in Dubai-UAE, ICBEC 2011.

E. Ceyhan, A. Kahraman, and M. Onder are with the Field Crops Department, University of Selcuk, Faculty of Agriculture, Konya, CO: 42075 Turkey (Tel.: 009033222328 56; fax: 009033224101 08; e-mail: eceyhan@selcuk.edu.tr). able to adjust to very different ecologies. In addition, the best plant growth and development takes place when there is an optimal level of environmental factors. Changing in environmental conditions may cause deterioration of plants to grow and develop to a certain extent. Accordingly, it will cause a change in the quality of the plants. Quality parameters seems to be particularly sensitive to environmental stress such as rainfall, light intensity, length of growing season, length of day, temperature as well as agronomic factors such as plant density, weeds, or soil fertility $[4,5,6,7,8]$.

The quality of crops is also affected by global climatic changes because a large number and complexity of factors such as growth assimilate partitioning and storage, pre- and post- harvest, including nutritional, technological and environmental factors [9].

Today, one of the main restrictive effective between environmental factors is drought. Abscisic acid is a plant hormone which has functions in many plant developmental processes. It also acts a part to protect plants against drought stress by closing stomas [10]. Figure 1 shows droughtinduced abscisic acid- dependent plant response.

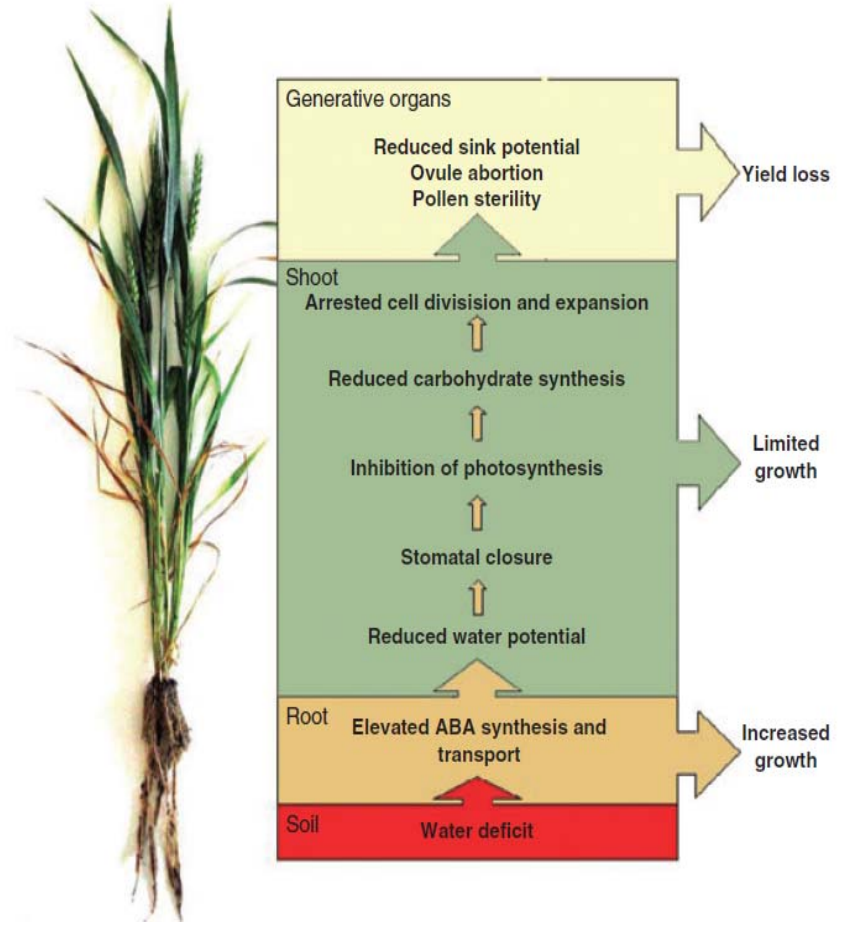

Fig. 1. Drought-induced abscisic acid- dependent plant response

Most of the foods are unknown in the sense of their nutritional value and their effects on human and animal. In this paper, we focus on the effects of environment on quality of plant products. 


\section{SOME QuAlity PARAMETERS AND EFFECTS OF ENVIRONMENT}

\section{A. Proteins}

Plant products are cheap and high quality sources of protein. While cereal grains have around $11 \%$ protein, legumes have $18-30 \%$ protein average. Legumes have higher amounts of amino acids such as thyptophan, lysine and aspartic acid. However, cereals have methionine, cystine, and glutamic acid more than legumes. The negative effects of unbalanced amino acids suppose to eliminate for optimal nutrition [5]. Protein content is one of the most important criteria used in determining the quality of plant products. Protein content is influenced largely by environmental factors $[6,7,8]$. External factors that affecting the amount of protein, are also the factors which affecting the duration of plant maturing periods. Protein decreases in grains after pollination because of the environment conditions which have rainy weather, cool and damp weather. However, if the weather is much rainy during vegetative development and it is hot and dry during generative growth period, the protein content increases. Environmental conditions also have important effects on the amino acids [8]. It is known that environmental factors are effective on the amino acid content of legumes [11].

Figure 2 shows a conceptual model of physiological responses of crops stimulated by five types of abiotic environmental stress, and their prevalent effects on quality parameters [12]

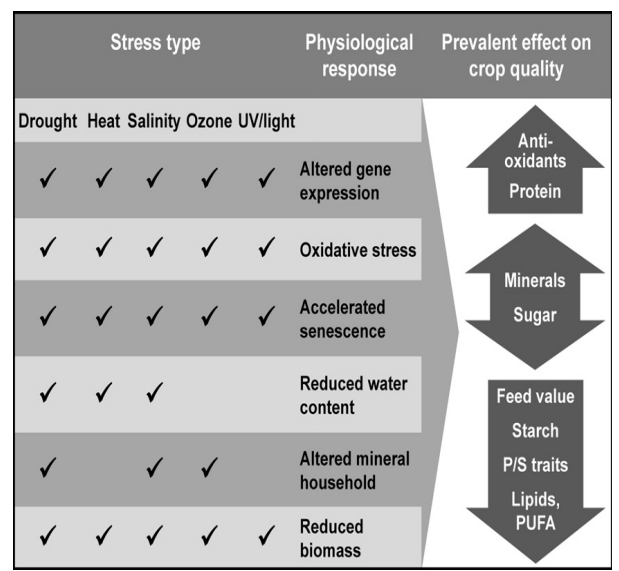

Fig. 2. Effects of abiotic environmental stress on quality parameters of crops

\section{B. Oils}

Vegetable oils have high nutritional value due to containing high proportion of polyunsaturated fatty acids and low proportion of saturated fatty acids. Environmental conditions effects growing and development, yield and oil quality of the plants in different ways. High temperature during growing period especially duration of seed development may influence the composition of fatty acids, and results lower quality of the oil. Despite the identification of fatty acids composition is determined by genetically, they are also changed by environmental conditions. More unsaturated fatty acid consists in cold climates and high altitudes [13]. Seed oil content and fatty acids in plants varies depending on environmental conditions by the time of developing stage. While environmental factors especially the minimum temperature and sunlight (solar radiation) has a significant influence on the concentration of sunflower oleic acid, the effect of maximum temperature has less importance. Linoleic acid content of sunflower is affected negatively by minimum temperature and sunlight [14]. It is possible that climate change would be harm to food production, especially in developing countries where they are located in tropical regions as a base of warmer climates [15]

\section{Mineral Substances}

Agricultural products are quite rich in terms of minerals especially potassium, phosphorus, calcium and iron. Mineral contents of plants affect a lot due to genotype and nutrition elements in the environment where they are grown. The amount of mineral contents especially iron, phosphorus and zinc are also influenced very much by environment $[16,8]$. It has been reported that most of macronutrients and micronutrients amounts were decreased in wheat and barley under high carbon dioxide concentrate and more affected in straw than in grains [17].

It has been reported that intensive water deficit treatment gave rise to importantly increased $\mathrm{Ca}(28 \%), \mathrm{Mg}(11 \%), \mathrm{Cu}$ $(18 \%)$, and $\mathrm{Zn}(33 \%)$ concentrations in maize grains while decreasing in $\mathrm{P}(17 \%)$, and $\mathrm{K}(17 \%)$ in the meanwhile compared with a fully watered treatment. Authors saw as that situation came true by lower soil moisture which leads to decreased availability of those minerals [18].

\section{Carbohydrates and Dietary Fibers}

Carbohydrates are occurred by sugar, starch and other polysaccharides. The functional properties of carbohydrates based on water absorption, swelling and solubility, gelatinization and viscosity, oil extraction and structural characteristics [19]. Baking and cooking under pressure facilitates the digestion of carbohydrates. The most important part of carbohydrates is dietary fibers which are organic non-digestible parts of foods. The constituent parts of dietary fibers are cellulose, hemicellulose, pectin and lignin. The first three of these are carbohydrate, but lignin is not a carbohydrate. A very large amount of fiber is concentrated in the seed coat. Therefore, peeling the shell reduces the amount of fiber [20]. While pectins, gums and some hemicelluloses in plant products are generally soluble dietary fiber sources, cellulose and some hemicelluloses are insoluble dietary fibers. Soluble and insoluble dietary fibers have shown positive effects on diet and weight loss [21, 22]. Insoluble dietary fiber consumption has an effect to reduce the risk of bowel cancer and heart diseases [22, 23]. Environment has important influences on the content of starch, carbohydrates and fibers [8].

\section{E. Enzyme Inhibitors}

Plants externalize individual shapes of ion transporters and enzymes that containing catalytic activities sufficient for the uptake and use of nutrients in the environment. They suppose to keep these ion transporters and catalytic proteins which are expressed at matching locations and timing to make ultimate the amount of nutrient assimilation. Not only increasing the capacities of transporters and enzymes, plants are also able to modifying their root architecture to be more effective accession to the mineral nutrients which are available in the soil [24]. Figure 3 shows an overview to root and regulatory elements. 


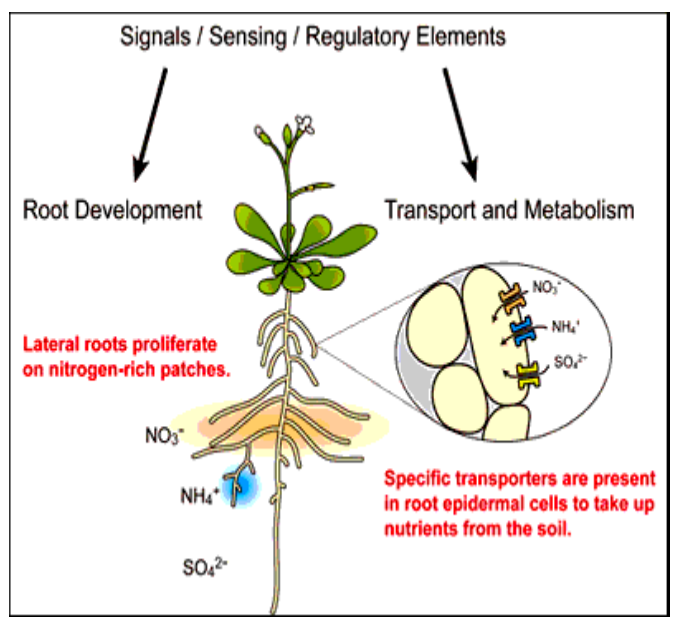

Fig. 3. An overview to root and regulatory elements

The livestock sector continues to develop technologies which are increasing the efficiency of natural resource use. These technologies target feed conversion because feed typically accounts around 60 to 70 percent of production costs. Better feed conversion saves land. Wide arrays of technologies have been improved for feed conversion. They are mainly used $\mathrm{n}$ industrial systems in industrial countries, but their use is quickly picking up in developing countries as well. One of the most important one is: improving digestibility by adding an enzyme (called phytase) that catalysis the digestion of phosphates contained in feed and reduces waste loads on the environment [25].

\section{E1. Protease inhibitors (Trypsin and Chymotrypsin)}

These are enzymes that break down certain proteins inhibit the functions, so that the protein digestion cannot be completed. These substances are broken down by heat during cooking and roasting. Trypsin is a protease inhibitor that situated naturally in the seed protein. Protease inhibitors are soluble proteins (albumin) that are included by soybean, bean, corn, rice, barley, peanut, potato, cocoa pods, animal tissues and various plant tissues. Environment has effect also with small amounts on especially trypsin content [8].

\section{E2. Amylase inhibitors}

Plants contain different amounts of alfa-amylase inhibitors that responsible for slowing digestion and give rise to changing of blood glucose and insulin responses [26]. These effects are beneficial for diabetics therefore present day many research is being done to improve diabetic products which contain alpha-amylase inhibitors. Amylase inhibitors are significantly affected by environmental conditions.

\section{E3. Oligosaccharides}

Legumes are known as a manufacturer of digestive gases. Animals and people are not capable of oligosaccharides digestion because of absence $\alpha$-galactosidase enzyme in mucous of digestive systems. As a result, $\alpha$-galaktocytes pass into the intestine and digested by intestinal bacteria owing to gas production [27]. Legume seed oligosaccharides commonly contain galactose such as raffinose, stachyose and verbascose which are the flatulent factors in humans and animals [28, 29]. Environment has effect also with small amounts on oligosaccharides [8].

\section{E4. Phenolic compounds}

There are large amounts of phenolic compounds in plants.
They protect plants against insect and animal damage. Major phenolic compounds in plants are phenolic acids, flavonoids, isoflavonoids and tocopherols. Phenolic compounds reduce to exploited some of the mineral substances such as zinc.

\section{E5. Tannins}

Tannins are quite complex group of plant secondary metabolites. They are dissolvable in polar solution and they are different from other polyphenolic compounds because of their capability to sediment proteins. Tannins are especially concentrated in the seed coot. The amounts of tannins are also important for animals.

High temperatures give rise to smaller and fibrous leaves that indicates changing of nutritional quality like reducing nitrogen and increasing tannins and phenols [30].

\section{E6. Isoflavones}

These are similar compounds to phytoestrogen that show both estrogenic and antiestrogenic activities in human exist various quantities in plants such as unrefined cereal grains, edible grain legumes, some fruits and vegetables [31].

\section{E7. Lectins (Hemaglutinins)}

They are carbohydrate binding proteins. They spread in multifarious plants and ingested daily perceivable amounts by humans and animals. They are able to survive digestion by the gastrointestinal system of consumers. Lectins provides to clotting of red blood cells. Plants contain a lot of lectin and these substances are broken down by heat [20].

\section{E8. Cyanogenic glycosides}

They consist of more than 20 compounds. There are many kinds of glycoside compounds show cytotoxic, antibacterial and other biological activities. These substances are important to their act in plant-herbivore interactions. Plants that varied greatly have toxic potential because of glycosides which are composed of HCN that a result of hydrolysis.

\section{E9. Saponins}

Saponins are a vast group of glycosides that distribute in higher plants. They have many wide ranges of biological properties especially as pharmacological. Legumes are major source of saponins that still working on because of cholesterol-lowering effects. Also there are many plants that used in traditional medicine contain saponins.

\section{E10. Phytic acids - Phytates}

Phytic acid is a free acid ester which consisted of myo-inositol ring and adherent inorganic phosphate. Chemical name is myo-inositol 1, 2, 3, 4, 5, 6 hexakis dihydrogen phosphate. Phytates are the $\mathrm{Ca}, \mathrm{Mg}, \mathrm{K}$ and $\mathrm{Fe}$ salt derivatives of phytic acide. Phytic acid and phytates are stored in plant seeds, feed grains, roots and tubers with widely different levels (0.1-6.0\%). Environmental conditions have slightly effect on phytic acid. In addition, phytic acid content of genotypes is affected by environmental conditions in different ways [8]. In diets, the procuration of Fe decreases by inhibition in lack of phytic acids and polyphenols. Determination of precise dispersion $\mathrm{Fe}$, phosphate, phytic acid and tannins therein the sorghum grains is needful to be able to improvement of more effective combinations of food processing methods which oriented to more eligible phytic acide-Fe molar ratios [32]. 


\section{Results AND SugGestions}

Plants often have sufficient to take the daily diet of protein, fat many vitamins (A, B, C, D and E) and minerals. The natural role of plant compounds is mainly for mission to protect plants from pathogens. The various effects of these compounds are entailed to interest for their potential chemotherapeutic impacts. In addition, as well as plants are important in human nutrition, they also important to animal nutrition. Still, phytic acide, phenolics, saponins, protease inhibitors, phytoestrogens and lignans have been related to reduced cancer risks [33]. These results entailed some debates such as the anti-cancer effects of soy isoflavones, especially genistein, in breast cancer prevention [34]. It is also well known that daily nutrient consumption such as from vitamin and mineral has importance to prevent cancer risk [35]. Polyphenols are also known as antioxidants and have importance to prevent of cardiovascular disease and some of cancer forms [36]. Practically, as accepted recently; one of anti-cancer plant is tea. Tea polyphenols are the major ingredients in green tea, and it has been suggested that their anti-carcinogenic effect is a result of their antioxidant activities, modulation of immunity, and activation of detoxification enzymes [37].

Due to superior nutritional value of plants influenced more or less by environmental conditions. From this perspective, the environmental conditions and soils to cultivate plants should be suitable. Plant agronomists, breeders, processors and all other relatives need pay attention to observation, study, evaluation and figuration about food quality to improve the plants which are capable of climate changes. As a result, the potential and new detected effects of plant compounds might be used in new approaches in medicine for humans. Therefore, more research is definitely needed.

\section{REFERENCES}

[1] N. Çelik and V. Bulur. Tarla Bitkileri Fizyolojisi. Uludağ Univ., Zir. Fak. Ders Notları No: 82, 1998.

[2] P. Högy and A. Fangmaier. Effects of elevated atmospheric $\mathrm{CO}_{2}$ on grain quality of wheat. Journal of Cereal Science. 2008, 48: 580-591.

[3] M. Van Pea and D. Berckmans. Quality of modeling plant responses for environment control purposes. Computers and Electronics in Agriculture. 22: 209-219, 1999.

[4] M. Harmankaya, S. Karadaş, C. Palta, and E. Ceyhan. Relationships between protein content and chemical compositions of local dry bean (Phaseolus vulgaris L.) genotypes grown in Central Anatolian Region of Turkey. Asian Journal of Chemistry. 21 (2), 1535-1540, 2008.

[5] M. Önder and A. Kahraman. Antinutritional Factors in Food Grain Legumes. $1^{\text {st }}$ International Syposium on Sustainable Development, volume 3, page 40-44, June 8-10, Sarajevo-Bosnia, 2009.

[6] L. A. McLean, F. W. Sosulski, and C. G. Youngs. Effects of nitrogen and moisture on yield and protein in field peas. Canadian Journal of Plant Science. 54: 301-305, 1974.

[7] E. Ceyhan, M. Harmankaya, and M. A. Avc1. Effects of Sowing Dates and Cultivars on Protein and Mineral Contents of Bean (Phaseolus vulgaris L.), Asian Journal of Chemistry. 20 (7), 5601-5613, 2008.

[8] N. Wang and J. K. Daun. Effects of variety and crude protein content on nutrients and anti-nutrients in lentils (Lens culinaris). Food Chemistry. 95: 493-502, 2006.

[9] R. Hay and J. Porter. The physiology of crop yield (Second edition). Oxford: Blackwell. 2006.

[10] B. Barnabas, K. Jager, and A. Feher. The effect of drought and heat stress on reproductive processes in cereals. Plant Cell Environment. 31: 11-38, 2008.

[11] A. A. Oshodi, K. O. Ipinmoroti, E. I. Adeyeye, and G. M. Hall. Amino and fatty acids composition of African yam bean (Phenostylis strenocarpa) flour. Food Chemistry. 53, 1-6, 1995.

[12] Y. Wang and M. Frei. Stressed food - The impact of abiotic environmental stress on crop quality. Agriculture, Ecosystems and Environment. 141: 271-286, 2011.
[13] B. Uppstrom. Seed Chemestry. Brassica oilseeds, production and utilization. CAB International Cambridge. 217-242, 1995.

[14] S. Gerald. Analysis of the relationships of environmental facors with seed oil and fatty acidconcentraions of wild annual sunflower. Field Crops Research. 15 (1): 57-72, 1986.

[15] T. N. Tubiello and G. Fischer. Reducing climate change impacts on agriculture: Global and regional effects of mitigation. Technological Forecasting and Social Science. 74: 1034-1056, 2007.

[16] E. Ceyhan. Variations in Grain Properties of Dry Bean (Phaseolus vulgaris L.). International Journal of Agricultural Research. 1 (2), 116-124, 2006.

[17] R. Manderscheid, J. Bender, H. J. Jager, and H. J. Weigel. Effects of season long carbon dioxide enrichment on cereals. II. Nutrient concentrations and grain quality. Agriculture, Ecosystems and Environment. 54: 175-185, 1995.

[18] D. G. Ti, F. G. Sui, S. A. Nie, N. B. Sun, H. A. Xiao, and C. L. Tong. Differential responses of yield and selected nutritional compositions to drought stress in summer maize grains. Journal of Plant Nutrition. 33: 1811-1818, 2010.

[19] R. Bressani and L. G. Elias. Seed Quality and Nutritional Goals in Pea, Lentil, Faba Bean and Chickpea Breeding. In: World Crops: Cool Season Food Legumes, Edited by R.J. Summerfield. 1988, Kluwer Academic Publishers.

[20] P. Devos. Mercimek ve nohutun besin değeri ve proses sırasındaki değişiklikler. Herkes İçin Mercimek Sempozyumu. 29-30 Eylül. Marmaris/Muğla, 174-196, 1988.

[21] J.W. Anderson and C. A. Bryant. Dietary fiber: Diabetes and obesity. Am. J. Gastroenterol. 81: 898- 906, 1986.

[22] J.A. Marlett, M. I. McBurney, and J. L. Slavin. Health implications of dietary fiber. J. Am. Diet Assoc. 102: 993-1000, 2002. (http://www.eatright.org/Public/GovernmentAffairs/92 adar2 0702.c fm).

[23] J. S. Hughes. Potential contribution of dry beandietary fiber to health. Food Technology. 45: 122-126, 1991.

[24] Anonymous. H. Takahashi. Research interests. www.bmb.msu.edu/faculty/takahashi.html. 2012.

[25] E. Lutz. Livestock and the environment: Issues and options. Agriculture and the environment/Perspectives on sustainable rural development. 283-302, 1998.

[26] F. M. Lajolo, F. F. Filho, and E. W. Menezes. Amylase inhibitors in Phaseolus vulgaris beans. Food Tech. 45: 119-121, 1991.

[27] S. E. Fleming. A study of relationships between flatus and carbohydrate distrubition in legume seeds. J. Food Sci. 46: 794-798, 1981.

[28] N. R. Reddy and D. Salunkhe. Changes in oligosaccharides during germination and cooking of black gram and fermentation of black gram rice blends. Cereal Chemistry. 57: 356-360, 1980.

[29] A. Aksar. Faba beans (Vicia faba L.) and their role in the human diet. Food and Nutrition Bulletin. 8: 15-24, 1986.

[30] J. I. L. Morrison and D. W. Lawlor. Interactions between increasing carbon dioxide concentration and temperature on plant growth. Plant, Cell and Environment. 22: 659-682, 1999.

[31] G. Kelly, A. Husband, and M. Waring. Monograph: Phenolic Phytoestrogens. Nat. Prod. Res. Consult. pp: 8, 1998.

[32] M. A. Slingerl, K. Traore, A. P. P. Kayodé, and C.E.S. Mitchikpe. Fighting Fe deficiency malnutrition in West Africa: an interdisciplinary programme on a food chain approach. NJAS - Wageningen Journal of Life Sciences. Volume 53, Issues 3-4, pp 253-279, 2006.

[33] L. U. Thompson. Potential health benefits and problems associated with antinutrients in foods. Food Research International. pp 131-149, 1993.

[34] K, Liu. Soy isoflavones: Chemistry, processing effects, health benefits, and commercial production. Soybeans as Functional Foods and Ingredients, chapter 3, 2004.

[35] A. A. Welch, A. A. Mulligan, R. N. Luben, and S. A. Bingham. Intake of selected vitamins and bioflavonoids from vitamin and mineral supplements by subjects in the EPIC-NORFOLK study, UK. Dietary Anticarcinogens and Antimutagens. pp 25-26, 2000.

[36] M. R. Olthof, E. Siebeling, P. C. H., Hollman, and M. B. Katan. Metabolism of chlorogenic acid, Quercetin3-rutinoside and black tea polyphenols in healthy volunteers. Dietary Anticarcinogens and Antimutagens. pp 73-75, 2000.

[37] C. Han and Y. Gong. Experimental studies on cancer chemoprevention by tea pigments. Dietary Anticarcinogens and Antimutagens. pp 203-212,

2000 